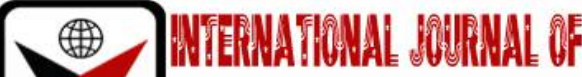

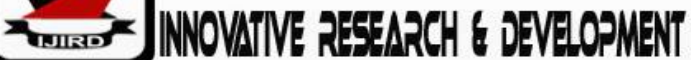

ISSN 2278 - 0211 (Online)

\section{Collective Bargaining and Industrial Harmony in Public Sector: A Study of Ebonyi State University Nigeria}

Hyginus Emeka Nwosu
Lecturer, Department of Accountancy/Business Administration/Banking and Finance,
Federal University, Ndufu Alike, Ebonyi State, Nigeria
Amadi Goodluck
Research Assistant, Department of Accountancy/Business Administration/Banking and
Finance, Federal University, Ndufu Alike, Ebonyi State Nigeria
Merit Okoh
Research Assistant, Department of Accountancy/Business Administration/Banking and
Finance, Federal University, Ndufu Alike, Ebonyi State, Nigeria

\section{Abstract:}

Collective bargaining and industrial harmony in public sector was elicits to determine the extent to which collective bargaining contributes to the industrial harmony in Ebonyi State University. The population of the study covers the broad spectrum of the 2678 staff of Ebonyi State University while the sample size of 348 was determined using Taro Yemeni's formula. The study made use of survey research design. Pre-tested structured questionnaire was adopted in data collection. Data was presented and analyzed with graphs and frequencies tables. Chi Square was employed to test the hypotheses. From the Findings, we discovered that collective bargaining prevents unfair labour practices in Ebonyi State University; that collective bargaining contributes to increase in productivity in Ebonyi State University; that collective bargaining is one of the effective tools through which conflict could be resolved in Ebonyi State University. The study therefore concludes that collective bargaining leads to industrial harmony in Ebonyi State University through improvement in conflict management which prevents unfair labour practices and leads to increase in productivity. Therefore, the study recommends among others that effective collective bargaining be practiced in all public organizations in Nigeria in order to foster industrial harmony.

Keywords: Industrial harmony, Collective bargaining, unfair labour practices, Workers' productivity, Conflict management

\section{Introduction}

\subsection{Background of the Study}

Nigeria has witnessed a huge increase in the number of industrial actions leading to strikes becoming endemic in Nigeria. The relationship between employers and employees is inherently conflictual because what is gained by workers in terms of wages are seen as cost by the employers. Conflict of interest is bane of conflict between the workers and their employers in many organizations and as such cannot be overlooked by the social partners in industrial relations. To show that conflict cannot be avoided by any management either in public or private sector, Fasan(2011) postulate that workers at all times seek for what is equivalent to their input to their organization in terms of labour and time while employers on their part will seek for the skills and potentials of workers and in exchange reward the efforts monetarily to such extent that could not affect their profit margins.

Collective bargaining constitutes an important means by which workers seek to satisfy their economic and social interest without necessarily going on strike. In the opinion of Esiagu, (2009) the stoppage of works whether by the employer or employee is detrimental to the production and economic well-being of the society as a whole, hence the need for industrial harmony. Industrial harmony enhances labour productivity and in turn improves performance in the education sector, achieving economic growth, and enhancing living standards and quality of life. In the words of Otobo, (2005) industrial harmony refers to a friendly and cooperative agreement on working relationships between employers and employees for their mutual benefit. In the light of the above, the study seeks to study the effect of collective bargaining on industrial harmony in public sectors using Ebonyi State University as a study area.

\subsection{Statement of Problem}

Nigeria has been witnessing numerous industrial disputes ranging from minor dispute with Local and State government establishments to the nationwide strikes. This may be as a result of poor management of Government 
establishment especially on issues that has to do with hour of work, salaries and wages, annual leave, allowances maternity leave, incessant lay-out of workers and in some situation complete liquidation of some organization. If relationships are poor, these differences may develop into confrontation which may in turn; result to open disputes involving either strike actions and stoppages or the failure of workers and management to cooperate fully.

\subsection{Objectives of the Study}

The main objective of the study is to determine the effect of collective bargaining on industrial harmony.

The specific objectives include:

- To determine how collective bargaining helps in cutting employers' unfair labour practices.

- To ascertain how collective bargaining contributes to increase in workers' productivity.

- To determine how collective bargaining improves conflict management.

\subsection{Research Question}

- How does collective bargaining help in cutting employers' unfair labour practices?

- How does collective bargaining contribute to increase in workers' productivity?

- To what extent does collective bargaining improve conflict management?

\subsection{Research Hypotheses}

- Ho: collective bargaining does not help in cutting employers' unfair labour practices.

- $\mathrm{Ho}_{2}$ : collective bargaining does not contribute to any increase in workers' productivity.

- $\mathrm{Ho}_{3}$ : collective bargaining does not improve conflict management.

\section{Review of Related Literature}

\subsection{Conceptual}

Many scholars have expressed their views about collective bargaining as an important tool in industrial harmony. According to Armstrong (2012), collective bargaining is the establishment by negotiation and discussion of agreement on matters of mutual concern to employers and unions covering the employment relationship and terms and conditions of employment. It can as well be seen as a mechanism whereby unions and management are brought together in an interactive process and each is given an opportunity to contribute to determination of matters which are mutually important to the parties and for the survival of the enterprise (Uchendu, 2003). Contributing on the merits of collective bargaining, Omoyibo (2002) in Ezeali and Esiagu (2009) maintain among other things that collective bargaining saves time, money and effort. They further opine that collective bargaining is used on negotiation of terms and conditions of employment with individual employees and enables individual employees to participate in taking decisions with management. Bello and Kinge (2014) maintain that one of the major functions of collective bargaining is to settle conflict between employers and employees in order to achieve industrial harmony. Industrial harmony refers to a friendly and cooperative agreement on working relationships between employers and employees for their mutual benefit (Otobo, 2005). Industrial harmony enhances labour productivity and in turn improves performance in our education sector, achieving economic growth, and enhancing living standards and quality of life. It creates a peaceful working environment conducive to tolerance, dialogue and other alternative means of resolving industrial or labour disputes in Nigeria. (Akuh, 2016).

The absence of collective bargaining in an organization breeds industrial dispute. Mamoria et al (2009) sees industrial dispute as the differences between employees and employers emanating from the employment and/or nonemployment terms. Conflict arises when after long negotiation the parties cannot reach a collective agreement and trade union decide to start industrial actions instead of continuing to negotiate (Owoseni,2014). collective bargaining is a veritable instrument for the management of conflict (Ekwoba et al (2015), and helps divert the energy that would have be used by workers in developing strategies on how to confront employers or government towards its performance which leads to efficiency and increase in productivity (Akpa and Namse, 2016). In the opinion of Humphery (1991), in Awe and Ayeni (2013) trade dispute does not only lead to low productivity but also reduction in the level of output and increase in average cost due to work stoppage. Collective bargaining can lead to higher performance of the employees when there is no dispute among them (Inya, 2015),

Anyim et al (2006) argued that collective bargaining is the main machinery by workers representatives and their employees not only to consider the demand of workers but also to resolve conflict in order to achieve organizational goals and objectives. It breeds atmosphere of mutual trust, confidence, cooperation harmonious relationship among employers, management and workers (Akpan and Namse, 2016); increased workers morale and commitment towards meeting performance target of public organizations ( Bello and Kinge, 2014).

\subsubsection{Collective Bargaining and Unfair Labour Practices}

The main function of collective bargaining is the reaching of collective argument that regulates the terms and conditions of employment (Oweseni, 2014). In the same light, Bello and Kinge (2014) opined that one of the major functions of collective bargaining is to settle conflict between employers and employees in order to achieve industrial harmony. Collective bargaining is vitally a rule making process. It states rules to be observed when labour is brought and sold, in the same measure that the state by legislation may regulate jobs. 
Appah and Emeh (2012) in Ekwoba et al (2015) states that collective bargaining establishes set rules guiding relationship between parties during life of collective agreement and also settling grievances that occur from time to time. In other words parties to collective bargaining have to lay down procedure which regulates their relationship as well as their behavior in settling disputes. Merrian Webster Law dictionary defined unfair labour practices is any of various acts by an employer or labor organization that violate a right or protection under applicable labor laws.

The main interest of trade union is in winning wage concessions from employers through collective bargaining. Where the employer fail to concur to the demands of the workers this could lead to strike. Thus collective bargaining should lead to industrial harmony by providing mechanism for settling disputes through negotiation working condition and terms of employment. Negotiation between parties must be conducted with a view to reaching an agreement. Collective bargaining therefore provides an avenue through which unions and management can accommodate each other numerous functions.

Collective bargaining provides a medium for discussing the problems of workers with their employers with their employers and help workers achieve reasonable wages, better working conditions and benefits. Collective bargaining is recognized as an instrument of social justice, it brings some equilibrium to unbalanced economic situations. It is an avenue through which the employers and employees settle their disputes which lead to industrial harmony and facilitates improvement in economic and trade performance.

Some researchers have carried out study on collective bargaining and recorded their findings. Ekwoba et al (2015), in their work collective bargaining: An evaluation of conflict management strategies found out that collective bargaining is a veritable instrument for the management of conflict. In other words collective bargaining prevents unfair labour practices by employers.

\subsubsection{Collective Bargaining and Increase in Productivity}

According to Okafor and Udu (2005) productivity is the rate at which work is done. Hence increase in productivity could be seen as an increase in the rate at which works are done and results achieved. Productivity can also be defined as output in a production process (Awe and Ayeni, 2013). Collective bargaining creates harmonious environment by limiting industrial dispute in workplace which fosters economic efficiency when both parties reach an agreement on salary, conditions of work etc. employees productivity is determined by the environment which an employed individual works. This work environment is very essential to the overall performance of employees in the organization (Makinde, 2013).

When cooperation and harmonious relationship exist among the relevant parties, it leads to attainment off organizational target performance by creating an atmosphere that fosters increase employee's morale and commitment. Collective bargaining enables flow of information between employees and from employers to employees. There is motivation and organization's specific investments are increased. This leads to increase in productivity because there is job security and peaceful atmosphere for workers and management to corporate. Akpa and Namse (2016), argued that collective agreement helps divert the energy that would have be used by workers in developing strategies on how to confront employers or government towards its performance which leads to efficiency and increase in productivity. Collective agreement reduces industrial actions that serves as impediment to industrial harmony and improve organizational efforts towards achievement of its stated goals.

Industrial dispute breeds atmosphere full ineffectiveness, inefficiency and low productivity. According to Humphery (1991), in Awe and Ayeni (2013) trade dispute does not only lead to low productivity but also to reduction in the level of output and increase in average cost due to work stoppage. Inya (2015), in her study 'collective bargaining as a veritable instrument for the settlement of industrial dispute' discovered that collective bargaining can lead to higher performance of the employees when there is no dispute among them.

\subsubsection{Collective Bargaining and Conflict Management}

According to Fashoyin (1980), collective bargaining is a machinery for discussion and negotiation, whether formal or informal, between employers and employees' representatives aimed at reaching mutual agreement or understanding on general employment relationship between the employer(s) and employees. Collective bargaining base on mutual benefits lead to positive outcome for both employers and employees. Employers and employees are two parties with conflicting interest. Employers are interested in managing the organization in such a way that the employees are motivated and their potentials and skills are channeled towards achievement of organizational goals and reward them to an extent that will not affect their profit margin while the employees are interested in securing the best terms and condition of employment. For organization to work effectively and harmoniously, these conflicting interests must be brought to equilibrium. Collective bargaining provides platform where workers and employers can jointly solve issues affecting them through dialogue, concessions and then consensus rather than through conflict and confrontation. Successful collective bargaining involves striking a balance of interest. It is a method that does not require employers to agree to terms they cannot fulfill. Agreements resulting from collective bargaining usually represent the choice or compromise of the parties themselves. It provides an institutionalize settlement through dialogue. A collective agreement provides method through which disputes between the parties can be settled. In that event the parties know beforehand that there is an agreed method by which disagreement may be resolved if such arises.

Collective bargaining is a form of employer-employee relations that allows employees to be heard in the work place on issues affecting them; it offers the employees the opportunity to speak with one voice. It enables them to preserve workplace integrity and respect, create safe and rewarding work environment. It provides union members with a voice to negotiate better wages, benefits and working conditions. Collective bargaining provides due process in the event of grievances or discipline issues where workers are not happy with the terms and condition of work this frequently leads 
to high labour turn over, high level of absenteeism and bad time keeping. This may also lead to slackness by individuals, poor working and deliberate time wasting.

Collective bargaining enables employers to make use of their most valuable resources which leads to increase in productivity. it leads to improvement in the administration and enforcement of workers' rights, facilities invested in training of workers and restrict discrimination by management between workers. Cooperation between management and workers is important to ensure industrial harmony in the organization.

In order to avoid industrial conflict between employers and employees in determining conditions and terms of employment collective bargaining is used. Anyim et al (2006), argued that collective bargaining is the main machinery by workers representatives and their employees to not consider the demand of workers but also to resolve conflict in order to achieve organizational goals and objectives. Ekwoba et al (2015), in their work collective bargaining: An evaluation of conflict management strategies found out that collective bargaining is a veritable instrument for the management of conflict. Akpan and Namse (2016), in their work collective bargaining: Its influence on workers' effectiveness in public sector discovered that collective bargaining breeds atmosphere of mutual trust, confidence, corporation harmonious relationship among employers, management and workers. Hence, fostering increased workers morale and commitment towards meeting performance target of public organizations. Another study conducted by Bello and Kinge (2014) on collective bargaining as a strategy for industrial conflict management revealed that collective bargaining plays active role in the management of industrial conflict which leads to dispute resolution.

\subsection{Theoretical Review}

The theory on which this work revolves is Pluralist Theory. The concept of pluralist is that industrial relation is a pluralist society. Fox (1966) in Armstrong (2012), says that industrial relation is a plural society having a related but different interest and objectives which must be brought to equilibrium. These separate interest and objectives are always in conflict with each other. The conflicts in the organization disrupt peace and efficiency. In order to have industrial harmony, this conflict is dealt with through collective bargaining which is viewed as very necessary if well managed.

\subsection{Empirical Review}

Various works have been done on related topics by different researchers. Some empirical evidences on collective bargaining are available.

Ekwoaba et al (2015), in their work Collective bargaining: An Evaluation of Conflict Management Strategies in the context of Lagos University of Nigeria. Data was collected via questionnaire, interviews and literature search and analyzed using descriptive statistics; frequencies and simple percentages wits. They came to a conclusion that; effective collective bargaining positively affects productivity and that collective bargaining is a veritable instrument for the management of conflict in the universities.

Another study was carried out by Akhaukwa et al (2012). They investigated the effect of collective bargaining process on Industrial Relation Environment in Public s Universities in Kenya. The data was collected based on stratified sample, expert judgment was used to determine the validity while Cronbach alpha coefficient was used to determine reliability off research instrument. Qualitative and quantitative data was analyzed using both descriptive and inferential statistics and linear regression analysis was employed to determine the effect of collective bargaining on industrial on industrial. They found that collective bargaining process has a significant effect on industrial relation on industrial relations environment.

Owoseni (2014) carried out a study on Collective Bargaining as a Veritable Tool for the Resolving Conflict in Organizations in the context of Ajayi Crowther University, Oyo, state Nigeria. The study made use of questionnaire for data gathering and the data was analyzed using frequency counts and simple percentages, regression analysis and T-test. The finding revealed that there was a significant difference between collective bargaining conflict resolutions.

Study carried out by Bello and Kinge (2014), on Collective Bargaining as a Strategy for Industrial Conflict Management in Taraba State Public Service (2007-2011). Primary and secondary sources of data were used, simple descriptive analysis and percentages were used for the purpose of data analysis and chi-square was used to test hypothesis. The study revealed that collective bargaining plays active role in the management of state wide conflict industrial conflict management in Taraba state and its role led to the resolution of the 2009 and2011 state wide strike.

Again Makinda (2013), conducted a study on securing a harmonious working environment through effective industrial relations at work place: the Nigerian perspective. The study was carried out at Kogi state using primary data sourced through administrative questionnaire. The response was tested using statistical tools like the simple percentage and the chi-square research techniques. Result revealed that harmonious working environment can be secured through effective industrial relations at workplace only that challenges confronting the unions has not make their activities effective in a way. A study carried out by

Inya (2015), on collective bargaining as veritable instrument for the settlement of industrial dispute in the context of Nigeria breweries plc, 9th mile, Enugu state data were collected through primary and secondary sources. Questionnaire were administered to respondents and analyzed by the use of frequency distribution tables and percentages and chisquare. The findings revealed that collective bargaining has a direct influence on dispute resolution in organizations. She also discovered that collective bargaining can lead to higher performance of the employees when there is as disputed among them and that collective bargaining resulted in maximization of profit and enhances industrial peace and harmony.

\section{Method}

The study made use of survey research design. The area of study Ebonyi State University was chosen because of its proximity to the researcher, have also existed for a reasonable number of years and as well experienced labour crises 
several times. This to a large extent enhances the researcher's chance of collecting valid and reliable data on collective bargaining and industrial harmony. The population of the study covers the broad spectrum of the 2678 staff of Ebonyi State University. The study made use of simple random sampling technique. The techniques provided each member of the entire target population equal and independent chance of being selected or included in the sample. However, Taro Yemeni's formula was adopted in determining the sample size. Descriptive statistics was employed in data presentation and analysis while Chi Square was employed in hypotheses testing.

\section{Test of Hypotheses and Discussion of Findings}

\section{1. test of Hypothesis One}

\begin{tabular}{|c|c|c|c|}
\hline & Observed N & Expected N & Residual \\
\hline 2.67 & 6 & 25.3 & -19.3 \\
\hline 3.00 & 4 & 25.3 & -21.3 \\
\hline 3.17 & 4 & 25.3 & -21.3 \\
\hline 3.33 & 7 & 25.3 & -18.3 \\
\hline 3.50 & 21 & 25.3 & -4.3 \\
\hline 3.67 & 14 & 25.3 & -11.3 \\
\hline 3.83 & 28 & 25.3 & 2.7 \\
\hline 4.00 & 89 & 25.3 & 63.7 \\
\hline 4.17 & 56 & 25.3 & 30.7 \\
\hline 4.33 & 60 & 25.3 & 34.7 \\
\hline 4.50 & 32 & 25.3 & 6.7 \\
\hline 4.67 & 6 & 25.3 & -19.3 \\
\hline 5.00 & 2 & 25.3 & -23.3 \\
\hline Total & 329 & & \\
\hline
\end{tabular}

Table 1: Frequencies Collective Bargaining and Unfair Labour Practices Source: Microsoft SPSS.

\begin{tabular}{|c|c|}
\hline & collective bargaining and unfair labour practices \\
\hline Chi-Square & $352.967 \mathrm{a}$ \\
\hline Df & 12 \\
\hline Asymp. Sig. & .000 \\
\hline
\end{tabular}

Source: Microsoft SPSS.

The decision rule that governs the acceptance or rejection of the null hypothesis is that if the calculated Chisquare $\left(x^{2}\right)$ value is greater than the table or critical Chi-square $\left(x^{2}\right)$ value, or if the significant value is less than the critical value or the table value which the test was carried out, the null hypothesis should be rejected otherwise the null hypothesis should be accepted.

With a Chi-square calculated value of 352.967, which is greater than the table or Chi-square $\left(x^{2}\right)$ value at ( $\mathrm{df}=12$ ) of 21.03 the null hypothesis should be rejected. This result is strengthened by the asymptotic significance value of 0.000 which is less than the critical value of 0.05 at which the test was carried out. Hence collective bargaining helps in cutting unfair labour practices.

\subsection{Test of Hypothesis Two}

\begin{tabular}{|c|c|c|c|}
\hline & Observed N & Expected N & Residual \\
\hline 3.00 & 6 & 27.4 & -21.4 \\
\hline 3.29 & 2 & 27.4 & -25.4 \\
\hline 3.57 & 8 & 27.4 & -19.4 \\
\hline 3.71 & 34 & 27.4 & 6.6 \\
\hline 3.86 & 44 & 27.4 & 16.6 \\
\hline 4.00 & 119 & 27.4 & 91.6 \\
\hline 4.14 & 34 & 27.4 & 6.6 \\
\hline 4.29 & 27 & 27.4 & -.4 \\
\hline 4.43 & 41 & 27.4 & 13.6 \\
\hline 4.57 & 8 & 27.4 & -19.4 \\
\hline 4.71 & 4 & 27.4 & -23.4 \\
\hline 4.86 & 2 & 27.4 & -25.4 \\
\hline Total & 329 & & \\
\hline
\end{tabular}

Table 3: Collective Bargaining and Increase in Productivity Source: Microsoft SPSS 


\begin{tabular}{|c|c|}
\hline & $\begin{array}{c}\text { Collective Bargaining and Increase } \\
\text { in Productivity }\end{array}$ \\
\hline Chi-Square & $437.213^{\mathrm{a}}$ \\
\hline Df & 11 \\
\hline Asymp. Sig. & .000 \\
\hline
\end{tabular}

Table 4: Test Statistics

Source: Microsoft SPSS

The decision rule that governs the acceptance or rejection of the null hypothesis is that if the calculated Chi-square $\left(x^{2}\right)$ value is greater than the table or critical Chi-square $\left(x^{2}\right)$ value, or if the significant value is less than the critical value or the table value which the test was carried out, the null hypothesis should be rejected otherwise the null hypothesis should be accepted. With a Chi-square calculated value of 437.213, which is greater than the table or Chi-square $\left(x^{2}\right)$ value at $(\mathrm{df}=11)$ of 19.68 the null hypothesis should be rejected. This result is strengthened by the asymptotic significance value of 0.000 which is less than the critical value of 0.05 at which the test was carried out. Hence collective bargaining prevents unfair labour practices.

\subsection{Test of Hypothesis Three}

\begin{tabular}{|c|c|c|c|}
\hline \multicolumn{4}{|c|}{$\begin{array}{c}\text { Mollective bargaining and Conflict } \\
\text { Management }\end{array}$} \\
\hline & $\begin{array}{c}\text { Observed } \\
\mathrm{N}\end{array}$ & $\begin{array}{c}\text { Expected } \\
\mathrm{N}\end{array}$ & Residual \\
\hline 3.38 & 2 & 25.3 & -23.3 \\
\hline 3.50 & 2 & 25.3 & -23.3 \\
\hline 3.63 & 4 & 25.3 & -21.3 \\
\hline 3.75 & 8 & 25.3 & -17.3 \\
\hline 3.88 & 22 & 25.3 & -3.3 \\
\hline 4.00 & 48 & 25.3 & 22.7 \\
\hline 4.13 & 61 & 25.3 & 35.7 \\
\hline 4.25 & 40 & 25.3 & 14.7 \\
\hline 4.38 & 64 & 25.3 & 38.7 \\
\hline 4.50 & 40 & 25.3 & 14.7 \\
\hline 4.63 & 16 & 25.3 & -9.3 \\
\hline 4.75 & 12 & 25.3 & -13.3 \\
\hline 4.88 & 10 & 25.3 & -15.3 \\
\hline Total & 329 & & \\
\hline \multicolumn{4}{|c|}{ Table 5 } \\
\hline
\end{tabular}

Source: Microsoft SPSS.

\begin{tabular}{|c|c|}
\hline & $\begin{array}{c}\text { collective bargaining and conflict } \\
\text { management }\end{array}$ \\
\hline Chi-Square & $239.720^{\mathrm{a}}$ \\
\hline Df & 12 \\
\hline Asymp. Sig. & .000 \\
\hline
\end{tabular}

Table 6: Test Statistics

Source: Microsoft SPSS

The decision rule that governs the acceptance or rejection of the null hypothesis is that if the calculated Chisquare $\left(x^{2}\right)$ value is greater than the table or critical Chi-square $\left(x^{2}\right)$ value, or if the significant value is less than the critical value or the table value which the test was carried out, the null hypothesis should be rejected otherwise the null hypothesis should be accepted. With a Chi-square calculated value of 239.720 , which is greater than the table or Chisquare $\left(x^{2}\right)$ value at $\mathrm{df}=12$ ) of 21.03 the null hypothesis should be rejected. This result is strengthened by the asymptotic significance value of 0.000 which is less than the critical value of 0.05 at which the test was carried out. Hence collective bargaining improves conflict management.

\subsection{Discussion of Findings}

From hypothesis one, we discovered that collective bargaining prevents unfair labour practices in Ebonyi State University. This finding was further strengthened by the asymptotic significance value of 0.000 which is lesser than the critical value of 0.05 at which the test was carried out. This further implies that; Collective bargaining curtailed the interference of employer with the formation of labour union, Collective bargaining helps to control employee discrimination in hiring of employee that discourages participation in union organization, Collective bargaining helps to control employee discrimination in tenure of employee that discourages participation in union organization, Collective 
bargaining assists in protecting employee against any discrimination that arises as a result of testifying against the employer, Collective bargaining helps to protect employee against any employer's threat and Collective bargaining protects the employee from employer's refusal to bargain with employee's representative.

Finding from hypothesis two revealed that collective bargaining contributes to increase in productivity in Ebonyi State University. This finding was that Collective bargaining helps to increase the performance of employees, Collective bargaining leads to employee's efficient maximization of materials, Collective bargaining encourages employees to put in more effort for the growth of the school, Collective bargaining encourages employees to put in more hours at work, Collective bargaining enhances effective utilization of employer's capital items to the success of the school, Collective bargaining creates atmosphere that fosters employees commitment, Industrial dispute essentially affects organizational productivity. Further strengthened by the asymptotic significance value of 0.000 which is lesser than the critical value of 0.05 at which the test was carried out. This finding is in line with Akpa and Namse (2016) and Inya (2015).

The finding concerning hypothesis three, was that collective bargaining is one of the effective tools through which conflict could be resolved in Ebonyi State University and that effective collective bargaining encourages joint decision making, promotes industrial democracy, leads to mutual trust, replaces weak individual attempt by workers and management to manage industrial dispute, leads to Increase in employees' confidence and leads to settlement of grievances. This assertion was further strengthened by the asymptotic significance value of 0.000 which is lesser than the critical value of 0.05 at which the test was carried out. This findings is in with Anyim et al (2006) and Bello and Kinge (2014).

\section{Summary of Findings}

This finding strengthened by the asymptotic significance value of 0.000 which is lesser than the critical value of 0.05 at which the test was carried out hence the following summary:

- That collective bargaining prevents unfair labour practices in Ebonyi State University.

- That collective bargaining contributes to increase in productivity in Ebonyi State University.

- That collective bargaining is one of the effective tools through which conflict could be resolved in Ebonyi State University.

\section{Conclusion}

It is quit revealing to conclude that collective bargaining leads to industrial harmony in Ebonyi State University through improvement in conflict management which prevents unfair labour practices and leads to increase in productivity. Therefore, effective collective bargaining should be practiced in all public organizations of Nigeria in order to foster industrial harmony.

\section{Recommendation}

Collective bargaining should be practiced in all establishments in order to forestall industrial dispute and enhance peace and harmony.

\section{References}

i. Akhaukwa J.0; Maru L. \& Byaruhanga. J. (2013), Relationship of Parties to Collective Bargaining and Industrial Relations Environment in Public Universities in Kenya, Mediterranean Journal of Social Sciences MCSER Publishing Rome-Italy E. ISSN 2039-21177, ISSN 2039-9340.

ii. Akpa E. I \& Namse M. (2010), Collective Bargaining: It's Influence on Workers' Effectiveness in Public sector, International Journal of Emerging Research in Management \& Technology, ISSN: 22773-9357 Vol.5, issue 8.

iii. Akuh (2016), Industrial Harmony for Academic Excellence: An Imperative for a Productive Educational System in Nigeria Published by European Center for Research and Development UK Vol.4 (4) pp63-71, may 2016. Online available@www.eajournals.org

iv. Anyim F. C., Elegbede F. \& Gbajumo M. A. (2011), Collective Bargaining Dynamic in Nigerian Public and Private Sectors', Australian Journals of Business and Management Research, Vol.1 (5) pp66-70.

v. Apah E. \& Emeh (2012), Employee Reporting and Collective Bargaining in Organization: A Need for Disclosure; Kuwait Chapter of Arabian Journal of Business and Management Vol.1 (8) pp23-36.

vi. Armstrong (2012), Armstrong's Handbook of Human Resource Management Practices page publishers, London.

vii. Avwokeni A.J. (2003), "Practical Research Methodology", (2 ${ }^{\text {nd }}$ Ed.), Port- Harcourt, Smart Publishing Co.

viii. Awe A.A \& Ayeni R. K (2013), Empirical Investigation into Industrial Relation and National Productivity in Nigeria, European Journal of Business and Management, ISSN 2222-2839, Vol. 5.( 8). Available online @www.iister.org.

ix. Baridan D. M (2000), Research Method Administrative Sciences, Port Harcourt Nigeria, Publishing House Choba

x. Bello M. F. \& Kinge R.F. (2014), Collective Bargaining as a strategy for Industrial Conflict Management in Taraba State Public Service (2007-2011), Department of Public Administration Namdi Azikiwe University Awka, Nigeria and Zainab Arabian Research Society for Multidisciplinary Issues Dubai, UAE ISSN:2315-77844 Vol.3 (6). Available online @jbmr.com/RPAM-index.php. 
xi. Chamberlain N. W. (1958), Collective Bargaining, New York. MC Graw-Hill.

xii. Chand Smriti (2016), Collective Bargaining: Meaning, Objectives and Important. Available online @www.yourarticlelibrary.com/hrm/collective-bargaining-meaning-objectives-and-important/354721.

xiii. Dunlop J. T (1958), Industrial Relations System, Carbondale and Edwards Ville, USA. Illinois University Press.

xiv. Ekwoaba J.O; Ideh D.A \& Ojikwu K.R (2012), Collective Bargaining: An Evaluation of Conflict Management Strategies in the Universities of Lagos, Nigeria, Journal of Emerging Trends in Economics and Management Sciences (JETEMS) 6(7) pp220-227. Available online @ Jetem.school.research.com.

xv. Ezeali B. 0 \& Esiagu. L.N (2009), Public Personnel Management: Human Capital Management Strategy in the 21st Century. Chambers book Ltd Onitsha, Nigeria.

xvi. Fasan, C. (2011), collective bargaining and corporate strategy: in published manuscript, Lagos state university, Nigeria.

xvii. Fashoyin Tayo (1980), Collective Bargaining in the Public Sector in Nigeria, London, Macmillan press.

xviii. Flander A. (1970), Management and Unions: The Theory and Reform of Industrial Relations, London, Faber and Faber.

xix. International Labour Organization (1960), Collective Bargaining: A Workers Education Manual, Geneva.

xx. Inya F. (2015), Collective Bargaining as a Veritable Instrument for the Settlement of Industrial Dispute, Unpublished Manuscript, Akanu Ibiam Federal Polytechnic Uwanna.

xxi. Makinde H. O. (2013), Securing a Harmonious Working Environment through Effective Industrial Relation at Workplace: The Nigerian Perspective, Business Management Dynamics Vol. 5. (2) pp46-51.

xxii. Merrian-Webster Law Dictionary. Available online @www.Merrian.com/legal/unfair\%20labour\%20practice.

xxiii. Nwachukwu, C. (2004), Human Resource Managements: (3rd edition). Port Harcourt, Nigeria university of Port Harcourt press.

xxiv. Okafor L.C. \& Ama A. U. (2005), Essentials of Business Management (2 ${ }^{\text {nd }}$ ed.), Enugu, Nigeria, Rhyee Kerex Publishers.

xxv. Onodugo V.A; Ugwuonuh G. E; \& Ebinne E.S. (2010), Social Science Research Principles, Methods and Applications" 76 Robinson Street, Uwani, Enugu, Enugu State Nigeria, EL DIEMAK Publishers.

xxvi. Otobo D. (2005), Industrial Relation: Theory and Controversies, (Revised ed.), Lagos Nigeria, Malthouse Press Ltd.

xxvii. Owoseni 0.0 (2014), Collective Bargaining as a Veritable Tool for Resolving Conflict in Organization, European Journal of Business and Management Vol. 6 (13).

xxviii. Sharma, R.D. \& Kumar (2014), Strike and Lockout as a Method of Collective Bargaining, International Journal of Research in Economics and Social Sciences, Vol. 4(6) pp 118-123.

xxix. Uchendu G. (2003), Industrial Relation in Nigeria, Issues, Theories and Practices, Owerri Imo State Nigeria, Computer Edge Publishers. 